\title{
The Impact of Zinc Oxide Nanoparticles on Male (In)Fertility
}

\author{
Ana Rita Pinho ${ }^{1,2}\left(\mathbb{D}\right.$, Sandra Rebelo ${ }^{1,2, *,+}$ (1) and Maria de Lourdes Pereira ${ }^{1,3, *, \dagger}$ \\ 1 Department of Medical Sciences, University of Aveiro, 3810-193 Aveiro, Portugal; arapinho@ua.pt \\ 2 Neuroscience and Signalling Laboratory, Institute of Biomedicine (iBiMED), 3810-193 Aveiro, Portugal \\ 3 CICECO-Aveiro Institute of Materials, University of Aveiro, 3810-193 Aveiro, Portugal \\ * Correspondence: srebelo@ua.pt (S.R.); mlourdespereira@ua.pt (M.d.L.P.); Tel.: +351-924-406-306 (S.R.); \\ +351-962702438 (M.d.L.P.); Fax: +351-234-372-587 (S.R.) \\ + These authors contributed equally for the work.
}

Received: 22 January 2020; Accepted: 9 February 2020; Published: 13 February 2020

\begin{abstract}
Zinc oxide nanoparticles (ZnO NPs) are among nanoscale materials, attracting increasing attention owing to their exceptional set of characteristics, which makes these engineered nanoparticles a great option for improving the quality and effectiveness of diagnosis and treatment. The capacity of $\mathrm{ZnONPs}$ to induce reactive oxygen species (ROS) production, DNA damage, and apoptosis represents a promise for their use in both cancer therapy and microbial treatment. However, their intrinsic toxicity together with their easy entrance and accumulation in organism have raised some concerns regarding the biomedical use of these NPs. Several studies have reported that ZnO NPs might induce cytotoxic effects on the male reproductive system, compromising male fertility. Despite some advances in this area, the knowledge of the effects of $\mathrm{ZnO}$ NPs on male fertility is still scarce. Overall, a brief outline of the major $\mathrm{ZnO}$ NPs biomedical applications and promises in terms of diagnostic and therapeutic use will also be explored. Further, this review intends to discuss the effect of $\mathrm{ZnO}$ NPs exposure on the male reproductive system and speculate their effects on male (in)fertility.
\end{abstract}

Keywords: ZnO nanoparticles; spermatogenesis; biomedicine; cytotoxicity; ROS; apoptosis

\section{Introduction}

Currently, nanoparticles (NPs) are defined as solid colloidal particles with less than $100 \mathrm{~nm}$ length/width in at least one dimension [1-3]. At the beginning of the 21st century, the interest in nanotechnology has emerged. Nanotechnology was defined as the study, manipulation, and control of matter at the nanometre scale according to its future application [2-4]. Interestingly, NPs are classified according to the material type used, dimension, morphology, composition, uniformity, agglomeration, and origin process. On the basis of the type of material used, NPs can be divided into four categories: metallic nanoparticles (e.g., Au, Ag, Cu, Fe, Zn NPs), metal and non-metal oxides (e.g., FeO, VO, $\mathrm{AlO}$, ZnO NPs), semiconductor nanoparticles (e.g., ZnS, CdSe, ZnSe, CdS NPs), and carbon-based NPs. Regarding the origin process, NPs are classified as natural or engineered. Engineered nanomaterials are produced by mechanical abrasion, engine exhaust, and smoke, or are synthesized by physical, chemical, or biological methods $[1,3,5,6]$. NPs have been synthesized in a wide variety of nanostructures.

Recently, there is growing interest in the metal oxide nanoparticles, like ZnO NPs, owing to their unique set of characteristics currently used for different approaches, from biomedicine to industry and agriculture. Zinc oxide can be referred as a multifunctional material owing to its unique physical and chemical properties. It is important to note that zinc ion $\left(\mathrm{Zn}^{2+}\right)$ is the most essential microelement found in all body tissues. $\mathrm{Zn}^{2+}$ is located intracellularly, being indispensable for metalloproteins' function, providing a unique platform for protein subdomains to interact with either DNA or other 
proteins (zinc finger motifs). These biological properties made the ZnO NPs an excellent option when compared with other metal nanoparticles, in part owing to its natural biocompatibility. Besides that, $\mathrm{Zn}^{2+}$ is an active element, and simultaneously a strong reducing agent that easily oxidizes, generating $\mathrm{ZnO}$. In fact, under normal conditions, the conversion of $\mathrm{Zn}^{2+}$ in $\mathrm{ZnO}$ is unidirectional. However, changes in $\mathrm{pH}$ and thermal conditions may induce the conversion of $\mathrm{ZnO}$ in $\mathrm{Zn}^{2+}$ [7]. Additionally, recent studies mention that the toxicity induced by ZnO NPs is because of the dissolution of $\mathrm{ZnO} N P s$ in $\mathrm{Zn}^{2+}$, altering the $\mathrm{Zn}^{2+}$ homeostasis, which is an important feature of the potential toxicity [8-10]. These nanoparticles present several advantages: High transparency, low toxicity, good size, good light trapping properties, natural abundancy, photoluminescence, good photocatalysis, inexpensive, good semiconductor, high catalytic organic transformation, chemical sensing, bound to several transition metal oxide nanoparticles, stable under UV radiation, and capable of generating reactive oxygen species (ROS) [5,11].

Nanobiotechnology has developed quickly and there is a huge variety of nanoparticles applications and preparation processes. However, this "nano-expansion" should be closely monitored as small amounts of nanoparticles are associated with high levels of toxicity, which could have an impact on environmental, animal, and human health. The broad application of ZnO NPs from the agriculture field to the textile industry makes humans constantly vulnerable to their exposure. Additionally, the development of biomedical applications, for example, in drug delivery systems, imaging, molecular diagnostics, and cancer therapy, has also raised some questions about ZnO NPs biosafety [5,11-13], and several studies addressed these issues.

Spermatogenesis is a complex process that originates highly specialized male reproductive cells. It comprises several regulated stages, from proliferation and differentiation of spermatogonia, meiosis, and spermiogenesis [14]. The spermatogonia cells suffer several mitotic divisions to both self-renew and produce undifferentiated diploid spermatogonia. Upon several rounds of differentiation and mitosis, spermatogonia originates the spermatocytes, which in turn suffers two meiotic divisions, and during the second spermatogenic phase, round haploid spermatids are produced. These spermatids are subjected to dramatical morphological alterations throughout the spermiogenesis, originating the elongated spermatids and finally the mature spermatozoa $[15,16]$. Recently, novel insights about the biological relevance of nuclear envelope proteins for mammalian spermatogenesis and male fertility were reviewed [17].

However, the $\mathrm{ZnO}$ NPs possible adverse effects on the male reproductive system are to date not well understood. Few studies have proposed ZnO NPs as a cytotoxic inducer in both testis and male germ cells, in a dose and time of exposure dependent manner. The aim of this review is to summarize the scientific contributions of the impact of $\mathrm{ZnO}$ nanoparticles for male reproductive cells' function, providing the discussion of these results and presenting future perspectives for the study of male (in) fertility.

\section{ZnO Nanoparticles, A Variety of Biomedical Applications}

Currently, there is a huge variety of ZnO NPs applications, from agriculture to the electronic industry and biomedical area. The conformational state of ZnO NPs means this type of nanoparticle is very promising and useful. There are several studies addressing the better NPs' conformation to answer the 21st century necessities.

The exceptional properties of $\mathrm{ZnO}$ NPs make them an excellent biomedical agent, being able to generate reactive oxygen species (ROS) and induce apoptosis, when used at high concentrations [18]. However, these NPs might be used as antioxidant agents at lower concentrations [19]. These are considered important characteristics for antimicrobial, anticancer, anti-inflammatory, and antidiabetic activities proposed for these NPs. Additionally, ZnO NPs can be used as a sperm protective agent from cryopreservation and diabetes injuries. Further, ZnO NPs have been successfully exploited as delivery systems of therapeutic agents and also as a bioimaging agent [11,12] (Figure 1). 


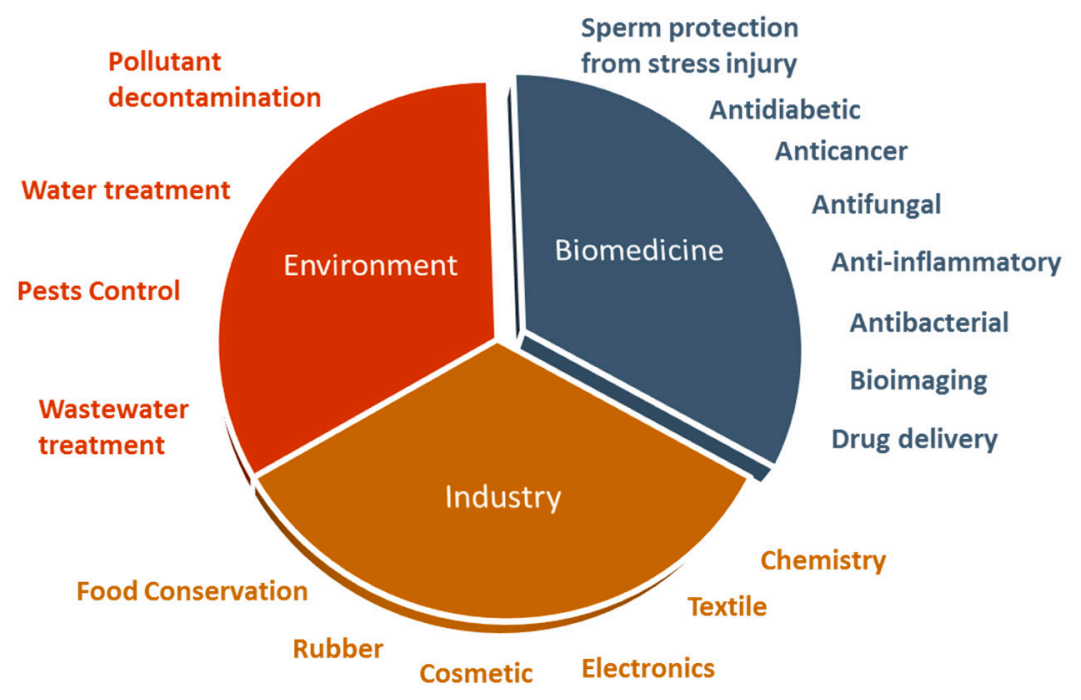

Figure 1. The $\mathrm{ZnO}$ nanoparticles, with a variety of applications in biomedicine, industry, and environment.

Although, is important to note that the effects of $\mathrm{ZnO}$ NPs depend on the size, the concentration used, the morphology, the synthesis process, the surface area, the cell type tested [20-22], and the organism type (only in the case of bacteria and fungi) [5,23-26]. Small sizes, higher concentrations, and high frequency of administration doses enhance its effects $[5,19,25,26]$.

$\mathrm{ZnO}$ NPs can be used as an antibacterial nanomaterial given their inherent properties, like high specific surface area and a high capacity to block a wide range of pathogenic agents [12]. ZnO NPs prevent bacteria adhesion, spreading, and breeding in medical devices, and are very useful in medical applications like pharmaceutical or cosmetic industries, as well as for textile modifications [12,27].

The main antibacterial toxicity mechanisms of $\mathrm{ZnO}$ NPs are based on their ability to increase ROS generation, especially when exposed to light $[12,24,28-30]$, causing peroxidation of the lipid membrane, leading to its dysfunction and consequent rupture [23,29]. Furthermore, the electrostatic interactions of $\mathrm{ZnO}$ NPs with the bacteria surface were revealed to be a possible antibacterial mechanism that caused membrane damage, especially with high ZnO NPs' concentrations [31,32]. These membrane alterations result from blockage of transport channels by ZnO NPs that causes starvation and eventually cell death [23]. Also, the antibacterial activity might involve the accumulation of ZnO NPs in the outer membrane or in the cytoplasm of bacterial cells triggering $\mathrm{Zn}^{2+}$ release, and thus bacterial cell membrane disintegration, active transport inhibition, membrane protein damage, and consequent genomic instability and alterations on membrane permeability [12,23,33-35].

Additionally, ZnO NPs are also considered antifungal agents, making them suitable for the food safety and agriculture industries [5,25,36,37]. Like in bacterial cells, the increased ROS production is the mainly cause of Candida albicans cell death and ZnO NPs' exposure to blue light enhances the oxidative stress [25]. A different study has shown that, besides ZnO NPs increasing the ROS levels, the growth inhibition verified in Botrytis cinerea and Penicillium expansum results from alterations on fungi morphology that are NPs' concentration-dependent [38]. Additionally, antifungal studies will be necessary to improve the potential applications of ZnO NPs as an antifungal agent, as the ZnO NPs' effects on yeast, for example, are still very scarce.

Besides antimicrobial activity, ZnO NPs could have potential anticancer properties and are considered a new alternative to cancer chemotherapy and radiotherapy. They are able to target multiple cancer cell types and simultaneously perform several key functions, including inhibiting cancer proliferation, drug-resistant cancer sensitization, preventing cancer recurrence and metastasizing, and reactivating cancer immunosurveillance [39]. ZnO NPs could be a selective anti-cancer agent, inducing higher ROS production in cancer cells when compared with normal cells and, together with 
the increased sensitivity for cancer cells, result in selective cell death of these tumoral cells $[5,40]$. These metal oxide NPs are able to alter the antioxidant mechanisms of cancer cells [18], leading to the activation of intracellular apoptosis signalling pathways [41] and consequent cell cycle arrest, preventing cell damage propagation to the daughter cells. [42]. Moreover, ZnO NPs exhibit a strong preferential ability to kill dividing cancer cells relatively to quiescent cells of the same lineage, suggesting that the mechanisms of $\mathrm{ZnO} N \mathrm{Ns}^{\prime}$ toxicity might be associated with the proliferative potential of the cells. This inherent differential toxicity raises exciting opportunities for NPs as anticancer agents. The selectivity of these nanomaterials can be improved by changing the NP design towards adding tumor targeting ligands to tumor-associated proteins, or by using NPs for drug delivery. These observations may provide the basis for the development of new rational strategies to protect against NPs toxicity or enhance the destruction of cancer cells [43].

Besides the use of ZnO NPs as anticancer activity, the loading of anticancer drugs into ZnO NPs presents some advantages that solve serious limitations of common drug carriers, such as enhancing the drug circulation for considerable periods of time, maintaining the relevant therapeutic concentrations, and facilitating the drug adsorption [44]. NPs are small enough to pass through the capillaries, to target specific sites of cancer cells, and also to allow a controlled release of the drug, reducing the overall amount of drug used and minimizing undesirable side effects. The innate anticancer activity of $\mathrm{ZnO}$ NPs combined with the therapeutic activity of the drug loaded contributes to a more effective drug cancer treatment. Furthermore, it provides better targeting of the highly toxic chemotherapeutic drugs as well as a controlled release of the drug, and showed low toxicity towards normal cells, producing very few side effects $[12,36,39,45,46]$. ZnO NPs might be also useful for DNA transfer, for real time imaging of gene transfer, for targeted gene delivery and gene silencing, and also for next-generation cancer applications [45,47].

Several studies have indicated that ZnO NPs have different mechanisms for inflammation inhibition that are very useful in autoimmune [43] and inflammatory diseases and in drug designing and targeting, as well as in the food and cosmetic industry. They may also offer a plausible solution for cancer and various types of inflammation treatment using, for instance, UV rays with minimal side-effects [39,48-50]. Interesting studies regarding atopic dermatitis revealed that ZnO NPs treatment decreases local skin inflammation on a mouse model with atopic dermatitis [51] and patients with atopic dermatitis [52], as a result of the anti-inflammatory properties of ZnO NPs [51,52], as well as high antioxidative and anti-bacterial capacities [52].

$\mathrm{ZnO}$ NPs might be used as a promising antidiabetic agent and diabetes complications reducer [12,53]. ZnO NPs effectively reverse diabetes-induced pancreatic structural, ultrastructural, and functional injuries [19,54]; normalize blood glucose [19,54] and serum insulin levels $[53,54]$; and restore the sensitivity of the insulin receptor to insulin [53]. This is explained because ZnO NPs might be an antioxidant agent at lower doses [19] and zinc acts directly on the insulin signalling pathway [12,55], improving hepatic glycogenesis.

Besides the role in insulin metabolism, the lower doses of ZnO NPs might have a protective effect on diabetes rat sperm, owing to their antioxidant properties. Sperm from diabetic rats is poor in number and sperm cells present a weak motility. Additionally, the serum testosterone levels are decreased. However, in the presence of ZnO NPs alone or in combination with insulin, an improvement in the quality of sperm and an increase of testosterone production is observed [56]. Moreover, ZnO NPs supplementation to nicotine exposed rats minimizes the harmful effects caused by exposure, through decreasing oxidative stress and increasing expression of steroidogenic enzymes, improving male fertility [57]. Also, ZnO NPs lower levels can protect the male reproductive system from damage induced by anticancer [58] and antibacterial drugs [59].

Furthermore, the use of $\mathrm{ZnO}$ NPs in sperm cryopreservation medium has been proven to be a protective factor to sperm, preventing common cell damage in cryopreserved sperm, namely DNA damage and cell membrane lipid peroxidation. Moreover, the acrosomal reaction is not altered in cells treated with $\mathrm{ZnO}$ NPs relative to control, meaning that this type of nanoparticles does not affect 
the cell fertility, increasing the motility of sperm compared with cryopreserved sperm [60]. However, the sperm underlying the protective mechanism is not well known and the majority of studies reported the $\mathrm{ZnO}$ NPs as a cytotoxic factor, as will be reviewed below.

\section{ZnO Nanoparticles: Route of Exposure and Accumulation in Organism}

Despite nanotechnology being a contemporary science, human exposure to nanoparticles has occurred throughout human history and dramatically increased during the industrial revolution [4]. Of note, when the industrial emissions do not fulfil the current environmental and public health safety standards, human exposition to NPs is inevitable and uncontrolled. Currently, despite that the industrial emissions standards are regulated, the number of NPs applications significantly increased, as described below. Furthermore, new NPs commercial applications have been developed, involving new properties, leading to new biological interactions and unexpected toxicity [61].

Owing to their small size, NPs have the ability to penetrate the skin, the lungs, the gastrointestinal tract, and also the blood brain barrier (BBB) [62]. These tissues, except the BBB, are in constant contact with the environment, facilitating the NP entrance. Additionally, injections and implants are other possible routes of exposure. Thus, nanoparticles can translocate into the circulatory and lymphatic systems, and ultimately to body tissues and cells, though interaction with subcellular structures [1].

$\mathrm{ZnO}$ NPs are a type of nanomaterial with a huge demand in biomedicine, industry, and agriculture, among other areas, meaning that the human exposure to these NPs is high, and like the generality of NPs, they can invade the human organism tissues and cells. ZnO NPs have been described as an easily accumulated nanomaterial, whose accumulation rate differs depending on the tissue type. Liver, kidney, lung, brain, and spleen are the organs with high ZnO NPs accumulation levels [63], presenting signals of cytotoxicity as a consequence of that exposure [64-67]. Besides that, metal nanoparticles have the capacity to cross the blood-testis barrier (BTB), in part by its size but also by the production of an inflammatory response that compromises the BTB integrity [62]. BTB controls the adluminal environment in which germ cells develop by influencing its chemical composition, so changes on BTB represent a risk to spermatogenesis [68,69]. It is possible to speculate that ZnO NPs may also cross the BTB, inducing testicular toxicity. Given the importance of this issue, this should be addressed in future studies. However, the knowledge on how ZnO NPs cross BTB is indispensable for assessing this toxic mechanism in the male reproductive system.

\section{ZnO Nanoparticles and their Effects on Male Reproductive System-Analysis of In Vitro and In Vivo Studies}

As described above, the variety of ZnO NPs applications is wide. Considering that human exposure to this type of metallic nanoparticle is high, it is relevant and essential to evaluate the effects of the ZnO NPs at several levels, including the histological, cellular, and molecular levels. Some studies have focused on the effects of ZnO NPs on spermatogenesis and have suggested that ZnO NPs have an impact on the male reproductive system. Tables 1 and 2 display representative studies, summarizing the main contributions of in vitro and in vivo studies, respectively.

\subsection{In Vitro Studies}

Only three in vitro studies were performed to evaluate the cytotoxic effects of ZnO NPs on the male reproductive system (Table 1). In vitro analyses of $\mathrm{ZnO}$ NPs effects on spermatogenesis, particularly on male germ cells, are scarce and mainly focused on cytotoxicity evaluation in different cell types. From all over the stages of spermatogenesis, the cytotoxicity of ZnO NPs was just analysed at very few cell stages, namely at the spermatocytes and spermatozoa, which indicates that their effect on male germ cells and consequently the reproductive system is not well established and deserves further investigation. In addition, the ZnO NPs effects on regulatory and supportive cells, Sertoli and Leydig cells, were also analysed and discussed. All the studies were performed using mouse cell lines, 
except one that was carried on human sperm samples. Viability, ROS production levels, DNA damage, and apoptosis levels were the parameters evaluated in these in vitro studies (Table 1).

As mentioned above, the BTB is a crucial component for normal spermatogenesis function. Previous studies evaluated the expression of tight junction proteins in Sertoli cells, namely claudin-5, occludin, ZO-1, and connexin-43, which promotes the adhesion between Sertoli cells forming the BTB [70]. As a consequence of ZnO NPs exposure, increased ROS production is observed and the expression of these BTB proteins is decreased [70,71] (Figure 2). The authors proposed that increased ROS production levels compromise BTB through down-regulating of tight junction proteins in Sertoli cells, leading to DNA damage and cell cycle arrest at the S-phase (Table 1). Further, it was also proposed that ROS possibly activates the Erk1/2 proteins, inducing an increase of tumor necrosis factor alpha (TNF- $\alpha$ ) cytokine levels, leading to alterations in tight junction proteins [72,73]. Therefore, it is possible to deduce that the integrity of BTB is altered in the presence of ZnO NPs, compromising the essential conditions for spermatogenesis progression [70]. To date, it is not known how the $\mathrm{ZnO}$ NPs cross the BTB, and this issue should definitely be explored in future studies.

Another interesting study defined the concentration of $1000 \mu \mathrm{g} / \mathrm{mL}$ of $\mathrm{ZnO} N P s$ as the cytotoxic dose for human sperm cells, given that a significant reduction in cell viability is observed. Additionally, the increase of cell mortality was observed 180 minutes after NPs exposure [74]. According to the results in Table 1, the cytotoxicity of ZnO NPs on the male reproductive system depends on concentration, time of exposure, and also cell type [70,71,74]. However, the structural characteristics of ZnO NPs, for example, size and surface area, were not considered as a variable of analysis. The cytotoxic effects of ZnO NPs were also evaluated using mouse spermatocytes [70]. The authors described an increase in DNA damage as well as cell cycle alterations. An increased expression in cell cycle proteins and an increased number of cells in S-phase and a decrease in the G1 and G2 phase. These alterations were reduced by the use of an antioxidant, indicating that oxidative stress plays a role in $\mathrm{ZnO}$ NPs cell cycle arrest [70] (Figure 2).

From all in vitro studies described, only two evaluated apoptosis in Leydig [71,75] and Sertoli cells after exposure to ZnO NPs [71]. These authors found that the apoptosis is associated with ROS formation, and with loss of mitochondrial membrane potential, which leads to the increase of apoptosis in Sertoli and Leydig cells associated with nuclear DNA damage [71,75] (Figure 2). These results clearly indicate a possible negative effect of $\mathrm{ZnO}$ NPs on spermatogenesis progression, as the number of Sertoli and Leydig apoptotic cells increases after exposure to these nanoparticles. In mouse Leydig cells, autophagy stimulated by oxidative stress might protect cells from ZnO NPs-induced apoptosis [75]. 
Table 1. In Vitro studies of ZnO nanoparticles (NPs) effects on male germ cells. Abbreviations: DNA, deoxyribonucleic acid; BTB, blood-testis barrier; DMEM, Dulbecco's modified Eagle's medium; GPx, glutathione peroxidase; GSH, reduced glutathione; MDA, malondialdehyde; RPMI, Roswell Park Memorial Institute medium; ROS, reactive oxygen species; MMP, mitochondrial membrane potential; ERK 1/2 : extracellular signal-regulated kinase 1/2; TNF- $\alpha$, tumor necrosis factor alpha; Bcl-2, B cell lymphoma-2; Bax, Bcl-2-associated X protein; LC3, microtubule-associated protein 1A/1B-light chain 3; Atg5, autophagy related 5.

\begin{tabular}{|c|c|c|c|c|c|c|}
\hline $\begin{array}{c}\text { ZnO NPs' } \\
\text { Characteristics }\end{array}$ & Objective & Cell Type & $\begin{array}{c}\text { ZnO NPs } \\
\text { Concentration } \\
(\mu \mathrm{g} / \mathrm{mL})\end{array}$ & Parameters & Results & Reference \\
\hline $\begin{array}{c}\text { Size: } 50 \mathrm{~nm} \\
\text { Shape: amorphous }\end{array}$ & $\begin{array}{l}\text { Evaluate the cytotoxicity of } \\
\text { ZnO NPs on viability of } \\
\text { spermatozoa }\end{array}$ & $\begin{array}{l}\text { Spermatozoa } \\
\text { (Human) }\end{array}$ & $10,100,500,1000$ & —Viability & $\begin{array}{l}\text { - The toxicity depends on } \\
\text { concentration and time of exposure; } \\
\text {-Higher concentrations and higher } \\
\text { exposure periods induce higher } \\
\text { toxicity }\end{array}$ & [74] \\
\hline $\begin{array}{c}\text { Size: } 70 \mathrm{~nm} \\
\text { Shape: spherical } \\
\text { Nature: crystalline } \\
\text { Dispersion: } \\
\text { polydisperse and } \\
\text { agglomerate in } \\
\text { quasi-spherical and } \\
\text { hexagonal structures } \\
\text { Surface roughness: } \\
\text { high }(22.9 \mathrm{~nm})\end{array}$ & $\begin{array}{l}\text { Investigate the toxicity of } \\
\text { ZnO NPs in testicular cells }\end{array}$ & $\begin{array}{l}\text { Leydig cell } \\
\text { Sertoli cell } \\
\text { (Mouse) }\end{array}$ & $0,5,10,15,20$ & $\begin{array}{l}\text {-Cellular uptake of } \mathrm{ZnO} \\
\text { NPs } \\
\text {-Viability } \\
\text {-MMP and ROS levels } \\
\text {-Apoptosis and DNA } \\
\text { Damage }\end{array}$ & $\begin{array}{l}\text { - ZnO NP aggregates in the } \\
\text { cytoplasm and in nucleus; } \\
\text { - The toxicity depends on the } \\
\text { concentration }(\geq 10 \mu \mathrm{g} / \mathrm{mL}) \text { and the } \\
\text { exposure time }(\geq 6 \mathrm{~h}) \text {, and not on } \mathrm{Zn}^{2+} \\
\text { release; } \\
\text { - ROS production increase, leading to } \\
\text { loss of MMP originating apoptosis of } \\
\text { Leydig and Sertoli cells and DNA } \\
\text { damage }\end{array}$ & [71] \\
\hline $\begin{array}{c}\text { Size: } 177 \mathrm{~nm} \\
\text { Shape: spheroid or } \\
\text { ellipsoid } \\
\text { Zeta Potential: } \\
-27.4 \pm 1.0 \mathrm{mV} \\
\text { Purity: }>97 \%\end{array}$ & $\begin{array}{l}\text { Explore the effects of } \\
\text { sublethal doses of ZnO NPs } \\
\text { and their underlying } \\
\text { mechanisms on male germ } \\
\text { cells }\end{array}$ & $\begin{array}{l}\text { Sertoli cell } \\
\text { Spermatocyte } \\
\text { (Mouse) }\end{array}$ & $\begin{array}{c}0,0.04,0.08,0.4,0.8,4 \\
8, \text { and } 16\end{array}$ & $\begin{array}{l}\text {-Viability } \\
\text {-ROS, GSH, and MDA } \\
\text { levels; } \\
\text {-Permeability, MMP, and } \\
\text { cytochrome C } \\
\text {-BTB junction proteins } \\
\text { levels; } \\
\text {-Erk1/2 and TNF- } \alpha \text { levels; } \\
\text {-DNA damage and cell } \\
\text { cycle; }\end{array}$ & $\begin{array}{l}\text { - The sublethal dose of } \mathrm{ZnO} \mathrm{NP} \text { is } 8 \\
\mu \mathrm{g} / \mathrm{mL} \text {; } \\
\text {-GSH levels decrease and MDA levels } \\
\text { increase; } \\
\text { - Sertoli cell membrane disruption and } \\
\text { cellular invasion; } \\
\text { - ROS levels production increase } \\
\text { compromising BTB, by } \\
\text { down-regulating the expression of } \\
\text { BTB junction proteins, causing DNA } \\
\text { damage and cell cycle arrest at S-phase } \\
\text { at spermatocytes }\end{array}$ & [70] \\
\hline $\begin{array}{l}\text { Size: } 30 \mathrm{~nm} \text {; } \\
\text { HS: } 66.36 \pm 0.39 \mathrm{~nm} \text {; } \\
\text { Zeta Potential: } \\
38.25 \pm 1.06 \mathrm{mV}\end{array}$ & $\begin{array}{l}\text { Investigate whether oxidative } \\
\text { stress was involved in } \mathrm{ZnO} \\
\text { NPs-induced apoptosis and } \\
\text { autophagy of mouse Leydig } \\
\text { cells, and to determine the } \\
\text { role of autophagy in } \mathrm{ZnO} \\
\text { NPs-induced apoptosis. }\end{array}$ & $\begin{array}{l}\text { Leydig cell } \\
\text { (Mouse) }\end{array}$ & $0,2,3,4$, and 8 & $\begin{array}{l}\text {-Cell Viability } \\
\text {-Bax, Bcl-2, cleaved } \\
\text { Caspase-3, cleaved } \\
\text { Caspase-8, LC3-I, LC3-II, } \\
\text { Atg5, and Beclin } 1 \text { protein } \\
\text { level from testis } \\
\text {-Cell biochemistry: SOD, } \\
\text { GPx, MDA, GSH }\end{array}$ & $\begin{array}{l}\text {-Cell viability inhibition and } \\
\text { apoptosis induction by oxidative } \\
\text { stress; } \\
\text {-Autophagy plays a cytoprotective } \\
\text { role in ZnO NPs-induced }\end{array}$ & [75] \\
\hline
\end{tabular}




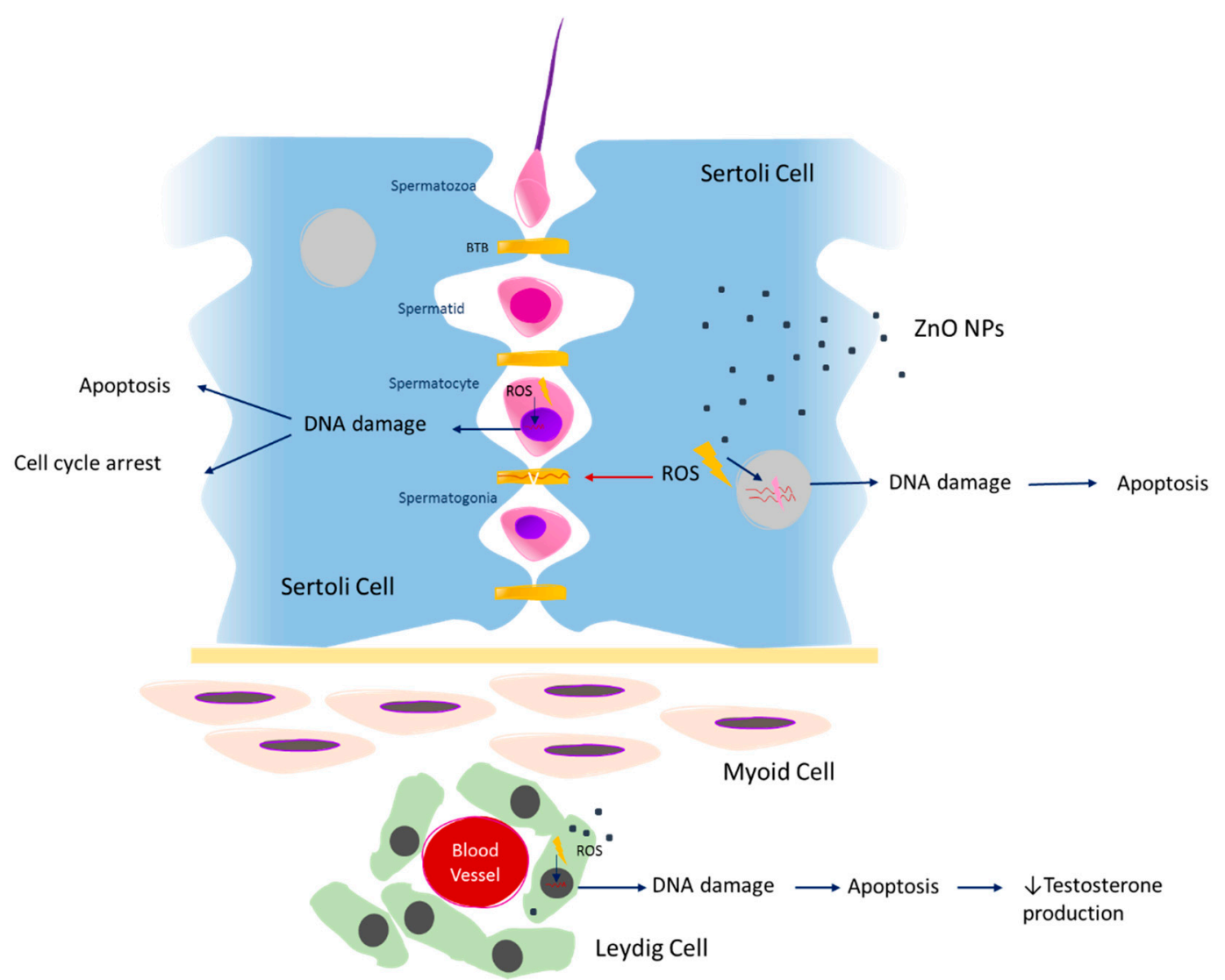

Figure 2. The cytotoxic effects of ZnO NPs on spermatogenesis. BTB-blood-testis barrier; ROS—reactive oxygen species; DNA—deoxyribonucleic acid; ZnO NPs—zinc oxide nanoparticles.

\subsection{In Vivo Studies}

Several animal models and routes of administration were used to study the in vivo consequences of $\mathrm{ZnO}$ NPs exposure on spermatogenesis. These in vivo studies evaluated the impact of ZnO NPs on the male reproductive system using different animal models (Table 2). This type of investigation is important to evaluate the histological and biochemical alterations observed in testis when exposed to ZnO NPs.

Most of these studies were performed in rodents using several techniques, including histological and biochemical analysis. In general, the parameters studied included testicular histology, seminiferous tubule (ST) diameter and epithelium height, oxidative stress, apoptosis, and genotoxicity markers. Most studies characterized $\mathrm{ZnO}$ NPs, although in some studies, that information was not available. 
Table 2. In Vivo studies of ZnO NPs effects on the male reproductive system and male fertility. Abbreviations: ZnO NPs, zinc oxide nanoparticles; CAT, catalase; CM, crystal morphology; HS, hydrodynamic size; MDA, malondialdehyde; SOD, superoxide dismutase; GPx, glutathione peroxidase; GRD, glutathione reductase; GSH, reduced glutathione; GST, glutathione S-transferase; TAC, total antioxidant capacity; GSI, gonadosomatic index; Ip, intraperitoneal; SA, surface area; SE, seminiferous epithelium, STD, seminiferous tubule diameter; GET, germinal epithelium thickness; $3 \beta$-HSD, $3 \beta$-hydroxysteroid dehydrogenase; $17 \beta$-HSD, $17 \beta$-hydroxysteroid dehydrogenases; Nr5A1, steroidogenic factor 1 (Nr5A1); Mrna, messenger ribonucleic acid; ROS, reactive oxygen species; MnPCEs, micronucleated polychromatic erythrocytes; DNA, deoxyribonucleic acid; TNF- $\alpha$, tumor necrosis factor alpha; IL-4, interleukin 4; LC3, microtubule-associated protein 1A/1B-light chain 3; Atg5, autophagy related 5; BIP, immunoglobulin-binding protein; XBP1s, X-box-binding protein 1 splicing; IRE1 $\alpha$, ER stress-associated gene inositol-requiring protein $1 \alpha$; JNK, jun kinase; C/EBP, CCAAT/enhancer binding protein; CHOP, C/EBP homologous protein; Bcl-2, B cell lymphoma-2; Bax, Bcl-2-associated X protein; StAR, steroidogenic acute regulatory protein.

\begin{tabular}{|c|c|c|c|c|c|c|c|}
\hline ZnO NPs Characteristics & Objective & $\begin{array}{c}\text { Animal } \\
\text { Model/Tissue or } \\
\text { Organ of Study }\end{array}$ & $\begin{array}{l}\text { Administration } \\
\text { via of Exposure }\end{array}$ & Evaluated Parameters & $\begin{array}{c}\mathrm{ZnO} \text { NPs } \\
\text { Concentration }\end{array}$ & Results & Reference \\
\hline & $\begin{array}{l}\text { Evaluate the effects of } \mathrm{ZnO} \\
\text { NPs on spermatogenesis }\end{array}$ & $\begin{array}{l}\text { NMRI mice } \\
\text { Semen } \\
\text { Testis }\end{array}$ & Oral & $\begin{array}{l}\text {-Epididymal sperm; } \\
\text {-Testicular histology; } \\
\text {-SE morphometry }\end{array}$ & $\begin{array}{c}0,5,50, \text { and } 300 \\
\mathrm{mg} / \mathrm{kg}\end{array}$ & $\begin{array}{l}\text {-Cytotoxicity in testicular germ } \\
\text { cells in a dose-dependent manner } \\
\text { ( } \geq 50 \mathrm{mg} / \mathrm{kg} \text { ): testis histological } \\
\text { alterations; } \\
\text {-Increased sperm abnormalities; } \\
\text { - Reduction of sperm and Leydig } \\
\text { cells number }\end{array}$ & {$[76]$} \\
\hline $\begin{array}{l}\text { Size: } 10-30 \mathrm{~nm} ; \\
\text { SA: } 20 / 30 \mathrm{~m}^{2} / \mathrm{g} ; \\
\text { Colour: milky white; } \\
\text { Crystal phase: single; } \\
\text { CM: nearly spherical; } \\
\text { Density: } 5.606 \mathrm{~g} / \mathrm{cm}^{3} \\
\text { Purity: } \geq 99 \%\end{array}$ & $\begin{array}{l}\text { Investigate the effects of } \\
\text { ZnO NPs on adult male } \\
\text { Wistar rats }\end{array}$ & $\begin{array}{c}\text { Wistar rats } \\
\text { Epididymis Sperm } \\
\text { Blood }\end{array}$ & Ip & $\begin{array}{l}\text {-Epididymal sperm; } \\
\text {-Serum biochemistry: SOD, } \\
\text { GPx, MDA, TOS, TAC }\end{array}$ & $\begin{array}{l}0,50,100,150 \text {, and } \\
200 \mathrm{mg} / \mathrm{kg}\end{array}$ & $\begin{array}{l}\text {-Viability and sperm number } \\
\text { decrease }(\geq 50 \mathrm{mg} / \mathrm{kg}) ; \\
\text { - Poor sperm quality }(\geq 100 \\
\mathrm{mg} / \mathrm{kg}) ; \\
\text {-Antioxidant capacity decrease } \\
(200 \mathrm{mg} / \mathrm{kg})\end{array}$ & [64] \\
\hline $\begin{array}{c}\text { Size: } 20 \mathrm{~nm} \\
\text { SA: }>90 \mathrm{~m}^{2} / \mathrm{g} \\
\text { Colour: white } \\
\text { CM: Nearly spherical } \\
\text { Purity: } \geq 99 \%\end{array}$ & $\begin{array}{l}\text { Investigate the effects of } \\
\text { ZnO NPs at different doses } \\
\text { on testis of adult mice }\end{array}$ & $\begin{array}{c}\text { NMRI male mice } \\
\text { Testis }\end{array}$ & Ip & —Testicular histology & $\begin{array}{c}0,250,500, \text { and } 700 \\
\mathrm{mg} / \mathrm{kg} \text { daily }\end{array}$ & $\begin{array}{l}\text { - Testis histological alterations; } \\
\text { - Reduction and degeneration of } \\
\text { spermatogonia, primary } \\
\text { spermatocyte, spermatid, sperm, } \\
\text { and Leydig cells; } \\
\text {-Spermatogenesis arrest }\end{array}$ & [77] \\
\hline $\begin{array}{c}\text { Size: } 70 \mathrm{~nm} \\
\text { Shape: spherical } \\
\text { Nature: crystalline } \\
\text { Dispersion: polydisperse } \\
\text { Surface roughness: high }(22.9 \mathrm{~nm})\end{array}$ & $\begin{array}{l}\text { Investigate the toxicity of } \\
\text { ZnO NPs in testicular cells }\end{array}$ & $\begin{array}{c}\text { Cd1 mice } \\
(21 \text { day old }) \\
\text { Epididymis Sperm } \\
\text { Testis }\end{array}$ & Intravenous & $\begin{array}{l}\text {-Sperm morphology; } \\
\text { —SE morphometry }\end{array}$ & 0,1 , and $5 \mathrm{mg} / \mathrm{kg}$ & $\begin{array}{l}\text { Spermatogenesis damage by } \\
\text { alteration of SE inducing sperm } \\
\text { abnormalities ( } \geq 5 \mathrm{mg} / \mathrm{kg} \text {, } \geq 49 \\
\text { days) }\end{array}$ & [71] \\
\hline
\end{tabular}


Table 2. Cont

\begin{tabular}{|c|c|c|c|c|c|c|c|}
\hline ZnO NPs Characteristics & Objective & $\begin{array}{c}\text { Animal } \\
\text { Model/Tissue or } \\
\text { Organ of Study }\end{array}$ & $\begin{array}{l}\text { Administration } \\
\text { via of Exposure }\end{array}$ & Evaluated Parameters & $\begin{array}{c}\mathrm{ZnO} \text { NPs } \\
\text { Concentration }\end{array}$ & Results & Reference \\
\hline $\begin{array}{l}\text { Size: }<50 \mathrm{~nm} ; \\
\text { SA: }>10.8 \mathrm{~m}^{2} / \mathrm{g} \\
\text { Purity: }>97 \% \text {; }\end{array}$ & $\begin{array}{l}\text { Evaluate the toxicological } \\
\text { effect of } \mathrm{ZnO} N \text { Ns on male } \\
\text { fertility and the } \\
\text { amelioration with querectin } \\
\text { in Wistar Han rats. }\end{array}$ & $\begin{array}{c}\text { Wistar Han rats } \\
\text { Epididymis Sperm } \\
\text { Testis }\end{array}$ & $\begin{array}{l}\text { Intragastric } \\
\text { intubation }\end{array}$ & 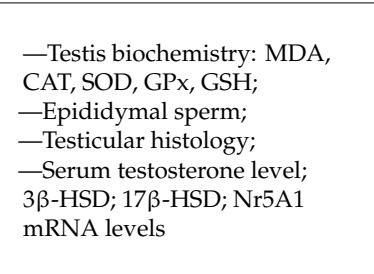 & $\begin{array}{c}0,100, \text { and } 400 \\
\mathrm{mg} / \mathrm{kg}\end{array}$ & $\begin{array}{l}\text {-Decrease of sperm live cell and } \\
\text { Leydig cell number; } \\
\text { - Serum testosterone level } \\
\text { decrease and increase of } \\
\text { abnormal sperm } \\
\text {-Atrophy, and necrosis of ST in a } \\
\text { dose-dependent manner; } \\
\text {-Antioxidant capacity decrease } \\
\text { and oxidative stress increase }\end{array}$ & [78] \\
\hline $\begin{array}{l}\text { Size: } 17.9 \pm 7-3 \mathrm{~nm} \\
\text { Distribution range: } 1-55 \mathrm{~nm} \\
\text { HS: } 721 \pm 109.5 \mathrm{~nm} \\
\quad \text { Purity: } \approx 100 \% \\
\text { Surface area: } 15-25 \mathrm{~g} / \mathrm{m}^{2}\end{array}$ & $\begin{array}{l}\text { Unravel the effects of } \mathrm{ZnO} \\
\text { NPs exposure on germ cell } \\
\text { apoptosis and } \\
\text { apoptosis-related gene } \\
\text { expressions }\end{array}$ & $\begin{array}{l}\text { Caenorhabditis } \\
\text { elegans } \\
\text { Egg }\end{array}$ & $\begin{array}{l}\text { Mix of } \mathrm{ZnO} \text { NPs or } \\
\mathrm{ZnCl}_{2} \text { into } \\
\text { nematode growth } \\
\text { medium (NGM) } \\
\text { agar }\end{array}$ & $\begin{array}{l}\text {-Apoptosis genes expression: } \\
\text { ced-13, ced-3, ced-4, ced-9, } \\
\text { cep-1, dpl-1, efl-1, efl-2, egl-1, } \\
\text { egl-38, lin-35, pax-2, and sir-2.1. }\end{array}$ & $\begin{array}{l}0,6.14 \times 10^{-1}, 61.4 \\
\text { and } 614 \mu \mathrm{M}\end{array}$ & $\begin{array}{l}\text { Apoptosis of germ cells ( } \geq 61,4 \\
\mu \mathrm{M}) \text { by upregulation of apoptosis } \\
\text { genes (cep-1, cep- } 13 \text {, efl-2, egl- } 1 \text {, } \\
\text { lin-35, and sir- } 2.1(\geq 614 \mu \mathrm{M}) \text {. } \\
\text { Enhanced apoptotic effects were } \\
\text { not fully attributed to ionic } \mathrm{Zn} \text {, } \\
\mathrm{ZnO} N \text { Ps also have the capacity } \\
\text { to affect apoptotic machinery }\end{array}$ & [79] \\
\hline Size: $80 \mathrm{~nm}$ & $\begin{array}{c}\text { Investigate side effects of } \\
\text { various doses of } \mathrm{ZnO} \mathrm{NPs} \\
\text { on the reproductive system } \\
\text { of albino mice }\end{array}$ & $\begin{array}{l}\text { Adult albino mice } \\
\text { Testis } \\
\text { Prostate } \\
\text { Seminal vesicles } \\
\text { Epididymis }\end{array}$ & Oral & $\begin{array}{l}\text {-Male reproductive system } \\
\text { histology }\end{array}$ & $\begin{array}{c}0,150, \text { and } 350 \\
\mathrm{mg} / \mathrm{kg}\end{array}$ & $\begin{array}{l}\text {-Cytotoxicity of testicular tissue } \\
\text { in a dose-dependent manner; } \\
\text {-Damages in all tissues of } \\
\text { reproductive system (testis, } \\
\text { seminal vesicles, prostate, and } \\
\text { epididymis }(350 \mathrm{mg} / \mathrm{kg}) \text { ) }\end{array}$ & [80] \\
\hline $\begin{array}{l}\text { Size: } 39.45+19.88 \mathrm{~nm} \\
\text { HS: } 447.5 \mathrm{~nm} \\
\text { Shape: hexagonal } \\
\text { Aggregation: large and irregular } \\
\text { Polydispersity index: } 0.13 \mathrm{~nm} \\
\text { Zeta Potential: }-32.1 \mathrm{mV}\end{array}$ & $\begin{array}{l}\text { Evaluate the genotoxic } \\
\text { effect of } \mathrm{ZnO} \mathrm{NPs} \mathrm{in} \mathrm{Swiss} \\
\text { mice }\end{array}$ & $\begin{array}{l}\text { Swiss male mice } \\
\text { Semen } \\
\text { Liver } \\
\text { Bone Marrow }\end{array}$ & Oral & $\begin{array}{l}\text {-Semen; } \\
\text {-Genotoxicity in blood samples: } \\
\text { CA, MnPCEs, DNA damage; } \\
\text {-ROS levels in liver }\end{array}$ & $300-2000 \mathrm{mg} / \mathrm{kg}$ & $\begin{array}{l}\text {-Genotoxic effects in a } \\
\text { dose-dependent manner by ROS } \\
\text { generation }(2000 \mathrm{mg} / \mathrm{kg}) \text { : leading } \\
\text { to genomic integrity and } \\
\text { anomalies in spermatogenesis; } \\
\text {-Chromosomal alterations and } \\
\text { generation of micronucleus in } \\
\text { bone marrow cells of male mice. }\end{array}$ & [81] \\
\hline Size: $10-30 \mathrm{~nm}$ & $\begin{array}{l}\text { Investigate the effect of } \mathrm{ZnO} \\
\text { NPs on some of the } \\
\text { antioxidant parameters of } \\
\text { semen plasma, quantitative } \\
\text { and qualitative properties of } \\
\text { Arabic ram sperm }\end{array}$ & $\begin{array}{l}\text { Arabic sheep } \\
\text { Semen }\end{array}$ & Oral & $\begin{array}{l}\text {-Semen; } \\
\text {-Membrane integrity; } \\
\text {-SOD and TAC }\end{array}$ & 0,40 , and $80 \mathrm{mg} / \mathrm{kg}$ & $\begin{array}{l}\text { Improves the qualitative and } \\
\text { quantitative properties of sperm } \\
\text { and some antioxidant parameters } \\
\text { of seminal plasma, neutralizing } \\
\text { the ROS effects }(80 \mathrm{mg} / \mathrm{kg}) \text {. }\end{array}$ & [82] \\
\hline
\end{tabular}


Table 2. Cont.

\begin{tabular}{|c|c|c|c|c|c|c|c|}
\hline ZnO NPs Characteristics & Objective & $\begin{array}{c}\text { Animal } \\
\text { Model/Tissue or } \\
\text { Organ of Study }\end{array}$ & $\begin{array}{l}\text { Administration } \\
\text { via of Exposure }\end{array}$ & Evaluated Parameters & $\begin{array}{c}\text { ZnO NPs } \\
\text { Concentration }\end{array}$ & Results & Reference \\
\hline $\begin{array}{l}\text { Size: } 10-30 \mathrm{~nm} \\
\text { Purity: } 99.9 \%\end{array}$ & $\begin{array}{l}\text { Investigate the effects of } \\
\text { different zinc source (nano, } \\
\text { organic, and inorganic) } \\
\text { supplementations on the } \\
\text { reproduction of male } \\
\text { Japanese quail. }\end{array}$ & $\begin{array}{c}\text { Japanese quail } \\
\text { chick (one-day old) } \\
\text { Testis } \\
\text { Eggs }\end{array}$ & Oral & $\begin{array}{l}\text {-Index of cloacal gland size; } \\
\text {-GSI; STD; GET; } \\
\text {-Serum testosterone level; } \\
\text {-Fertility; } \\
\text { - Hatchability }\end{array}$ & 0,25 , and $50 \mathrm{mg} / \mathrm{kg}$ & $\begin{array}{l}\text { Detrimental effects on } \\
\text { reproduction, by reducing } \\
\text { hatchability and, also, inducing } \\
\text { abnormalities in Japanese quail } \\
\text { embryos }\end{array}$ & [83] \\
\hline $\begin{array}{l}\text { Size: } 50 \mathrm{~nm} \text {; } \\
\text { Shape: cube; } \\
\text { Colour: White } \\
\text { Purity: } 99.99 \% \text {; }\end{array}$ & $\begin{array}{l}\text { Evaluate the effects of } \mathrm{ZnO} \\
\text { NPs on the weight of } \\
\text { epididymis, testis, seminal } \\
\text { vesicle, and prostate and } \\
\text { identify abnormalities of } \\
\text { epididymis sperm of albino } \\
\text { rats }\end{array}$ & $\begin{array}{l}\text { NMRI male mice } \\
\text { Testis } \\
\text { Seminal Vesicles } \\
\text { Prostate } \\
\text { Sperm Epididymis }\end{array}$ & Oral & $\begin{array}{l}\text {-Testis, epididymis, seminal } \\
\text { vesicle, and prostate histology; } \\
\text { - Testis, epididymis, seminal } \\
\text { vesicle, and prostate weights }\end{array}$ & $\begin{array}{l}0,100, \text { and } \\
200 \mathrm{mg} / \mathrm{kg}\end{array}$ & $\begin{array}{l}\text { - Testicular and epididymis } \\
\text { weight decrease and hypertrophy } \\
\text { of seminal vesicle and prostate; } \\
\text {-Increase of epididymal sperm } \\
\text { abnormalities }\end{array}$ & [84] \\
\hline $\begin{array}{l}\text { Size: }<100 \mathrm{~nm} \text {; } \\
\text { Purity: } \geq 99.5 \% \\
\text { Colour: white }\end{array}$ & $\begin{array}{l}\text { Detect the effects of } \mathrm{ZnO} \\
\text { NPs on the testes and } \\
\text { prostate of adult albino rats } \\
\text { and recovery }\end{array}$ & $\begin{array}{l}\text { Male albino rats } \\
\text { Serum } \\
\text { Testis } \\
\text { Prostate }\end{array}$ & Oral & $\begin{array}{l}\text {-Serum biochemistry: MDA, } \\
\text { GSH, CAT, SOD; } \\
\text { - Testicular and prostatic } \\
\text { cytokines: TNF- } \alpha \text {, IL-4; } \\
\text {-DNA fragmentation; } \\
\text { - Testis and prostate histology }\end{array}$ & 0 and $422 \mathrm{mg} / \mathrm{kg}$ & $\begin{array}{l}\text {-Increase of oxidative stress and } \\
\text { decrease of antioxidant capacity } \\
\text { in serum; } \\
\text { - Inflammatory response and } \\
\text { DNA fragmentation increase, in } \\
\text { testis and prostate and } \\
\text { histological changes; } \\
\text {-Limited exposure to ZnO NPs } \\
\text { allows recovery of damaged } \\
\text { tissue }\end{array}$ & [85] \\
\hline $\begin{array}{c}\text { Size: } 30 \mathrm{~nm} ; \\
\text { HS: } 66.36 \pm 0.39 \mathrm{~nm} ; \\
\text { Zeta Potential: } 38.25 \pm 1.06 \mathrm{mV}\end{array}$ & $\begin{array}{l}\text { Investigate whether } \\
\text { oxidative stress was } \\
\text { involved in } \\
\text { ZnO NPs-induced } \\
\text { apoptosis and autophagy of } \\
\text { mouse Leydig cells, and to } \\
\text { determine the role of } \\
\text { Autophagy in } \mathrm{ZnO} \\
\text { NPs-induced apoptosis. }\end{array}$ & $\begin{array}{l}\text { Male Kunming } \\
\text { mice } \\
\text { Serum } \\
\text { Epididymis Sperm } \\
\text { Testis }\end{array}$ & Intragastric & $\begin{array}{l}\text {-Serum testosterone level; } \\
\text {-Testis and epididymis } \\
\text { histology; } \\
\text {-Bax, cleaved Caspase-3, } \\
\text { cleaved Caspase-8, LC3-I, } \\
\text { LC3-II, Atg5, and Beclin } 1 \\
\text { protein level from testis }\end{array}$ & $\begin{array}{l}0,100,200 \text {, and } \\
400 \mathrm{mg} / \mathrm{kg}\end{array}$ & $\begin{array}{l}\text {-Disruption and atrophy of the } \\
\text { SE by apoptosis and germ cell } \\
\text { depletion; } \\
\text {-Decrease of epididymal sperm } \\
\text { density and serum testosterone } \\
\text { level; } \\
\text {-Induction of autophagy in testis } \\
\text { tissue }\end{array}$ & [75] \\
\hline $\begin{array}{c}\text { Size: } 30 \mathrm{~nm} ; \\
\text { Shape: spherical }\end{array}$ & $\begin{array}{l}\text { Evaluate the potential } \\
\text { reproductive risks in males } \\
\text { exposed by gavage to } \\
\text { various doses of } \mathrm{ZnO} \mathrm{NPs}\end{array}$ & $\begin{array}{l}\text { Male Kunming } \\
\text { mice } \\
\text { Serum } \\
\text { Epididymis Sperm } \\
\text { Testis }\end{array}$ & Ip & $\begin{array}{l}\text {-Serum testosterone level; } \\
\text {-Zinc accumulation; } \\
\text { - Testis histology } \\
\text {-Gene expression in Testis: BIP, } \\
\text { XBP1s, IRE1 } \alpha, \text { JNK, C/EBP, } \\
\text { CHOP, Bax, Bcl-2, Caspase 12, } \\
\text { Caspase 13, StAR, P450sc }\end{array}$ & $\begin{array}{c}0,50,150 \text {, and } \\
450 \mathrm{mg} / \mathrm{kg}\end{array}$ & $\begin{array}{l}\text {-Accumulation of nanoparticles } \\
\text { contributed to seminiferous } \\
\text { tubules degeneration and sperm } \\
\text { cell number diminution via } \\
\text { apoptosis and ER-stress } \\
\text { signalling pathway; } \\
\text {-Decrease testosterone } \\
\text { production through the } \\
\text { downregulation of StAR. }\end{array}$ & [86] \\
\hline
\end{tabular}




\subsubsection{In Vivo Studies in Mammalian Animal Models}

Most of the in vivo studies reported in Table 2 evaluate changes in testicular and epididymal tissues after exposure of rats or mice to different $\mathrm{ZnO}$ NPs concentrations. The histological pattern was similar in both rats or mice, with the formation of multinucleated giant cells [76,77], disorganization of germ cells layers, detachment and sloughing of immature germ cells, and vacuolization of the epithelium of ST after exposure to a high concentrations of ZnO NPs [75-78,80,86]. These histological alterations are indicative of functional damage in Sertoli cells, which are responsible for the support and protection of germ cells during spermatogenesis [76].

Spermatogenesis arrest has been described as a consequence of exposure to high $\mathrm{ZnO}$ NPs concentrations [75-78,80]. The appearance of immature germinal cells in the epididymis [77], as well as degenerated and desquamated spermatocytes [77,78] and sperm cells [77] in the STs lumen and epididymis, respectively, is evident. In addition, the number of germinative cells is reduced [75-78,86] and the STs of Wistar Han rats were almost empty of spermatids and spermatozoa after exposure to $400 \mathrm{mg} / \mathrm{kg}$ of ZnO NPs. The number of Leydig cells, an important cell responsible for testosterone production, also decreased in exposed animals $[87,88]$. These results are consistent with data obtained from in vitro study using a Leydig cell line, which reports a decrease in Leydig cells' viability and an increase of apoptosis after in vitro exposure to ZnO NPs [71] (Figure 2). Furthermore, according to a recent study, the testis toxicity after exposure to ZnO NPs occurs via apoptosis and the ER-stress signaling pathway, activated by ROS [86].

Additionally, analysing the morphology of seminiferous tubules, a decrease in the diameter and height of the epithelium resulting from germ cell loss is notable, owing to the apoptotic effect of $\mathrm{ZnO}$ NPs on spermatogenic cells $[71,76,77,83]$. In addition to the testis and epididymis, other studies analysed histological changes in seminal vesicles and prostate [80], with an increase in their weight [84]. The occurrence of inflammation in the dilated area of prostate acini and the hyperplasia of epithelial lining cells of prostatic acini was detected in mice and rats exposed to ZnO NPs $[80,85]$. In seminal vesicles, the changes were also significative, with the detection of mononuclear cells infiltrating the stroma and the appearance of mild to moderate proliferation of epithelial cells [80]. According to these data, exposure to $\mathrm{ZnO}$ NPs has repercussions on all male reproductive systems in a dose-dependent manner.

Regarding the sperm quantity and quality, ZnO NPs cause harmful effects, reducing the number and motility of sperm cells and increasing the number of morphological abnormalities such as double head, small head, formless head, and double tail $[64,71,76,78,81,84]$. A significant reduction in sperm viability has also been observed in several studies [64,78,81]. Interestingly, Hussein et al., 2016 revealed that these changes in sperm quality could be alleviated by co-exposure with quercetin, a potent antioxidant. The number of Leydig cells also decreases after exposure to a low concentration of $\mathrm{ZnO}$ NPs, and as a consequence, serum testosterone levels decrease, as reported in Wistar Han rats [78] and Kunming mice [75,86]. Additionally, the same authors explored the influence of $\mathrm{ZnO}$ NPs on steroidogenesis enzymes by assessing the mRNA levels of steroidogenic proteins in testis samples, namely $3 \beta$-hydroxysteroid dehydrogenase ( $3 \beta$-HSD), $17 \beta$-hydroxysteroid dehydrogenases (17 $\beta$-HSD), and steroidogenic factor 1 (Nr5A1) [78]. These are enzymes responsible for the conversion of pregnenolone, a cholesterol derivative, into progesterone and androstenedione, a progesterone derivative, in testosterone, respectively [87]. Nr5A1 is a transcription factor that regulates the expression of several steroidogenic enzymatic genes on Leydig cells (such as $3 \beta-\mathrm{HSD}$ and aromatase) and is involved in the steroidogenesis pathway and synthesis of testosterone [88]. Moreover, a recent study reported a significant down-regulation of steroidogenic acute regulatory protein (StAR) in testis, very important in testosterone synthesis, responsible for the transport of hydrophobic low-density cholesterol from the cytosol to the mitochondrial inner membrane [86,89]. The expression of mRNA steroidogenic proteins showed a significant decrease in ZnO NPs-exposed groups, which justifies the lowering in serological testosterone levels $[78,86]$. 
As mentioned in previous studies, $\mathrm{ZnO}$ NPs are a source of oxidative stress owing to their accumulation on liver. In order to evaluate antioxidant parameters in rats and mice, some studies analysed the activity of superoxide dismutase (SOD), glutathione peroxidase (GPx), reduced glutathione (GSH), catalase (CAT), and total antioxidant capacity (TAC). The levels of lipid peroxidation marker malondialdehyde (MDA) and of total oxidant status (TOS) were also assessed to evaluate the oxidative stress. A significant reduction was found in the activity of antioxidant enzymes (CAT, SOD, GPx) and of GSH [78], just as TAC was decreased in the blood sample of rats $[64,85]$. TOS and the lipid peroxidation level have been shown to increase significantly after exposure to a high concentration of ZnO NPs $[64,78,85]$. Thus, ZnO NPs may be considered an inhibitor of the antioxidant machinery and an oxidative stress inducer. A reduction in sperm viability occurs as a result of ROS formation in liver. ROS induce chromosomal alterations in blood samples and DNA damage, indicating that rats exposed to a high concentration of $\mathrm{ZnO}$ NPs have higher levels of ROS in organism that induce apoptosis of the sperm cell [81].

Contrary to the majority of studies, sheep exposure to ZnO NPs improved the sperm parameters and neutralized the effects of ROS by increasing its antioxidant activity. These results are attributed to the zinc antioxidant activity and its role in the stabilization of sperm according to the study. According to the authors, it is important to note that different animal species have differential nutritional requirements for spermatogenesis, and until now, there are no in vivo published studies about the effect of ZnO NPs on spermatogenesis reported in any other animal model than rodents. In addition, the dose of ZnO NPs is lower compared with other studies. Thus, future studies are needed to clarify these results, repeating the study with higher doses of exposure [82].

\subsubsection{In Vivo Studies in Non-Mammalian Animal Models}

Non-mammalian in vivo studies have similar results to those obtained from mammalian in vivo studies. In testis from Japanese quail treated with ZnO NPs, the morphological analysis of ST revealed a decrease in diameter and height of the epithelium, as observed in mammalian in vivo studies resulting from germ cell loss, and an apoptotic effect of ZnO NPs on spermatogenic cells. Further, the serum testosterone levels decreased with exposure to ZnO NPs. In addition to the histological analysis of the Japanese quail testis, egg hatchability was also evaluated after sperm exposure to different concentrations of ZnO NPs, to assess the sperm functionality. The cytotoxic effects of ZnO NPs in sperm cells have repercussions in fertility, causing infertility and a higher incidence of embryonic deaths, reducing hatchability rates and inducing teratogenic effects on their embryos [83]. These results emphasize the importance of toxicity study in male germ cells, once ZnO NPs are capable to reduce the fertility from Japanese quail.

The effect of ZnO NPs exposure on germ cell death was also evaluated in C. elegans. Exposure of $C$. elegans to $\mathrm{ZnO}$ NPs caused an increase in the apoptotic cell number, resulting from a change in apoptotic gene regulation. The apoptotic genes cep-1, cep-13, efl-2, egl-1, lin-35, and sir-2.1 were significantly upregulated in the presence of ZnO NPs, promoting cell apoptosis [79]. Although it is necessary to be aware that this animal model is hermaphrodite, in this study, no distinction was made between germ cells. Thus, it is necessary to study the expression of upregulated genes in male mammalian cells to better understand the apoptosis mechanism behind ZnO NPs in germ cells.

\section{Conclusions and Future Perspectives}

The applications of ZnO NPs in biomedicine are numerous, given the multiple advantages conferred by the physicochemical properties of these nanomaterials. However, these nanoparticles induce significative cytotoxic effects on spermatogenesis. These cytotoxic effects are dose and time of exposure dependent, indicating that a high concentration and a high time of exposure induce more toxicity. Toxicity is normally induced by increased ROS production and by inhibition of antioxidant cell response, inducing DNA damage, with cell cycle arrest culminating in apoptosis of male germ cells. 
The same occurs with Sertoli and Leydig cells, whose role of support and regulation of spermatogenesis is well known (Figure 2).

Oxidative stress also has an important harmful effect on Sertoli cells besides apoptosis, as the tight junctions suffer significative effects that might compromise the spermatogenesis progression (Figure 2). Histological analysis revealed sloughing and denaturation of male germ cells and disorganization of germ cells layers as a consequence of ZnO NPs exposure. Regarding Leydig cells, the histological analysis indicated a decrease of their number as a consequence of the rat's exposure to ZnO NPs. The serum levels of testosterone also decreased, which also compromises the spermatogenesis progression, which is testosterone-dependent. These reductions were explained by the decreased expression of steroidogenic proteins in testes samples, the decreased mitochondrial membrane potential, and the increased apoptosis in Leydig cells.

The study of $\mathrm{ZnO} N P$ s effects on male fertility is still scarce, mainly at the in vitro and in vivo levels. It is important to extend the cytotoxic evaluation of $\mathrm{ZnO} N P s$ to the first cell stage of spermatogenesis, spermatogonia, and later stages to understand whether ZnO NPs are capable of compromising all spermatogenesis or whether their harmful effects are reversible. Further, the sperm fertilization capacity is an important parameter that should be determined in mammalian exposed to $\mathrm{ZnO} N P$ s, in order to understand their direct effect in male fertility. In future, it is important to address cytotoxicity and histotoxicity studies in human samples, given the scarcity of such an approach.

Besides that, it will be interesting to investigate ways to control the toxic effects of ZnO NPs reported so far. Several studies have developed new forms of conjugating ZnO NPs with other materials that reduced natural cytotoxicity. The toxicity of these new nanocomplexes also needs to be investigated in testicular cells. In addition, it is important to note that all studies evaluate ZnO NPs toxicity based on concentration and exposure time, but the effects of any NP also depend on their physicochemical properties. Thus, future studies should be conducted to assess their effects on the male reproductive system based on size, surface area, and method of synthesis.

Author Contributions: Conceptualization, S.R. and M.d.L.P.; methodology, S.R., M.d.L.P. and A.R.P.; investigation, A.R.P.; data curation, A.R.P.; writing — original draft preparation, A.R.P.; writing-review and editing, A.R.P.; visualization, S.R. and M.d.L.P.; supervision, S.R. and M.d.L.P.; project administration, S.R. and M.d.L.P.; funding acquisition, S.R. and M.d.L.P. All authors have read and agreed to the published version of the manuscript.

Funding: This work was supported by the Instituto de Biomedicina -iBiMED (UIDB/04501/2020 and POCI-01-0145-FEDER-007628); and the Fundação para a Ciência e Tecnologia (FCT) of the Ministério da Educação e Ciência, the COMPETE program, QREN, and the EU (Fundo Europeu de Desenvolvimento Regional). The authors acknowledge support from the project 'Wisdom-Impact of wide-spread proteome aggregation through aging in mammals and implications for the development of age-related diseases' (PTDC/BTM-TEC/29843/2017) and the Integrated Programme of SR\&TD 'pAGE-Protein aggregation across lifespan' (CENTRO-01-0145-FEDER-000003), co-funded by Centro 2020 Program, Portugal 2020, EU, through the European Regional Development Fund. This work was developed within the scope of the project CICECO-Aveiro Institute of Materials, UIDB/50011/2020 \& UIDP/50011/2020, financed by national funds through the FCT/MEC, and when appropriate co-financed by FEDER under the PT2020 Partnership Agreement.

Conflicts of Interest: The authors declare no conflict of interest. The funders had no role in the design of the study; in the collection, analyses, or interpretation of data; in the writing of the manuscript, or in the decision to publish the results.

\section{References}

1. Buzea, C.; Pacheco, I.I.; Robbie, K. Nanomaterials and nanoparticles: Sources and toxicity. Biointerphases 2007, 2, 17-71. [CrossRef] [PubMed]

2. United Kingdom Royal Society. Nanoscience and nanotechnologies: Opportunities and uncertainties. Neuroradiology 2004, 46, 618. [CrossRef]

3. Jeevanandam, J.; Barhoum, A.; Chan, Y.S.; Dufresne, A.; Danquah, M.K. Review on nanoparticles and nanostructured materials: History, sources, toxicity and regulations. Beilstein J. Nanotechnol. 2018, 9, 1050-1074. [CrossRef]

4. Hulla, J.E.; Sahu, S.C.; Hayes, A.W. Nanotechnology: History and future. Hum. Exp. Toxicol. 2015, 34, 1318-1321. [CrossRef] [PubMed] 
5. Król, A.; Pomastowski, P.; Rafińska, K.; Railean-Plugaru, V.; Buszewski, B. Zinc oxide nanoparticles: Synthesis, antiseptic activity and toxicity mechanism. Adv. Colloid Interface Sci. 2017, 249, 37-52. [CrossRef] [PubMed]

6. Heiligtag, F.J.; Niederberger, M. The fascinating world of nanoparticle research. Mater. Today 2013, 16, 262-271. [CrossRef]

7. Wang, N.; Tong, T.; Xie, M.; Gaillard, J.-F. Lifetime and dissolution kinetics of zinc oxide nanoparticles in aqueous media. Nanotechnology 2016, 27, 1-24. [CrossRef]

8. Saptarshi, S.R.; Duschl, A.; Lopata, A.L. Biological reactivity of zinc oxide nanoparticles with mammalian test systems: An overview. Nanomedicine 2015, 10, 2075-2092. [CrossRef] [PubMed]

9. Senapati, V.A.; Kumar, A. ZnO nanoparticles dissolution, penetration and toxicity in human epidermal cells. Influence of pH. Environ. Chem. Lett. 2018, 16, 1129-1135. [CrossRef]

10. Cho, W.S.; Duffin, R.; Howie, S.E.; Scotton, C.J.; Wallace, W.A.; MacNee, W.; Bradley, M.; Megson, I.L.; Donaldson, K. Progressive severe lung injury by zinc oxide nanoparticles; the role of $\mathrm{Zn}^{2+}$ dissolution inside lysosomes. Part. Fibre Toxicol. 2011, 8, 27. [CrossRef] [PubMed]

11. Madhumitha, G.; Elango, G.; Roopan, S.M. Biotechnological aspects of ZnO nanoparticles: Overview on synthesis and its applications. Appl. Microbiol. Biotechnol. 2016, 100, 571-581. [CrossRef] [PubMed]

12. Jiang, J.; Pi, J.; Cai, J. The Advancing of Zinc Oxide Nanoparticles for Biomedical Applications. Bioinorg. Chem. Appl. 2018, 2018, 1-18. [CrossRef] [PubMed]

13. Larson, J.K.; Carvan, M.J.; Hutz, R.J. Engineered Nanomaterials: An Emerging Class of Novel Endocrine Disruptors1. Biol. Reprod. 2014, 91, 1-8. [CrossRef] [PubMed]

14. Sharma, R.; Agarwal, A. Spermatogenesis: An Overview. In Sperm Chromatin; Springer: Berlin/Heidelberg, Germany, 2011; pp. 127-160.

15. Guraya, S.S. Biology of Spermatogenesis and Spermatozoa in Mammals; Springer: Berlin/Heidelberg, Germany, 1987.

16. Hess, R.A.; de Franca, L.R. Spermatogenesis and Cycle of the Seminiferous Epithelium. Adv. Exp. Med. Biol. 2008, 636, 1-15. [CrossRef]

17. Pereira, C.D.; Serrano, J.B.; Martins, F.; da Cruz e Silva, O.A.B.; Rebelo, S. Nuclear envelope dynamics during mammalian spermatogenesis: New insights on male fertility. Biol. Rev. 2019, 94, 1195-1219. [CrossRef]

18. Wang, C.; Hu, X.; Gao, Y.; Ji, Y. ZnO Nanoparticles Treatment Induces Apoptosis by Increasing Intracellular ROS Levels in LTEP-a-2 Cells. BioMed Res. Int. 2015, 2015, 1-9. [CrossRef]

19. Umrani, R.D.; Paknikar, K.M. Zinc oxide nanoparticles show antidiabetic activity in streptozotocin-induced Type 1 and 2 diabetic rats. Nanomedicine 2014, 9, 89-104. [CrossRef]

20. Nagajyothi, P.; Sreekanth, T.; Tettey, C.O.; Jun, Y.I.; Mook, S.H. Characterization, antibacterial, antioxidant, and cytotoxic activities of $\mathrm{ZnO}$ nanoparticles using Coptidis Rhizoma. Bioorg. Med. Chem. Lett. 2014, 24, 4298-4303. [CrossRef]

21. Rad, S.S.; Sani, A.M.; Mohseni, S. Biosynthesis, characterization and antimicrobial activities of zinc oxide nanoparticles from leaf extract of Mentha pulegium (L.). Microb. Pathog. 2019, 131, 239-245. [CrossRef]

22. De Souza, R.C.; Haberbeck, L.U.; Riella, H.G.; Ribeiro, D.H.B.; Carciofi, B.A.M. Antibacterial activity of zinc oxide nanoparticles synthesized by solochemical process. Braz. J. Chem. Eng. 2019, 36, 885-893. [CrossRef]

23. Dutta, R.; Nenavathu, B.P.; Gangishetty, M.K.; Reddy, A. Studies on antibacterial activity of ZnO nanoparticles by ROS induced lipid peroxidation. Colloids Surf. B Biointerfaces 2012, 94, 143-150. [CrossRef] [PubMed]

24. Zhang, Z.-Y.; Xiong, H.-M. Photoluminescent ZnO nanoparticles and their biological applications. Materials 2015, 8, 3101-3127. [CrossRef]

25. Lipovsky, A.; Nitzan, Y.; Gedanken, A.; Lubart, R. Antifungal activity of ZnO nanoparticles-the role of ROS mediated cell injury. Nanotechnology 2011, 22, 1-5. [CrossRef] [PubMed]

26. Yoshikawa, A.H.; Possebon, L.; Costa, S.D.S. Adverse effects of Metal-based Nanoparticles on Male Reproductive Cells. In Top 10 Contributions on Environmental Health, 2nd ed.; AvidScience: Berlin, Germany, 2018; pp. 1-19.

27. Pasquet, J.; Chevalier, Y.; Couval, E.; Bouvier, D.; Noizet, G.; Morlière, C.; Bolzinger, M.-A. Antimicrobial activity of zinc oxide particles on five micro-organisms of the Challenge Tests related to their physicochemical properties. Int. J. Pharm. 2014, 460, 92-100. [CrossRef] [PubMed]

28. Applerot, G.; Lipovsky, A.; Dror, R.; Perkas, N.; Nitzan, Y.; Lubart, R.; Gedanken, A. Enhanced antibacterial actiwity of nanocrystalline $\mathrm{ZnO}$ due to increased ROS-mediated cell injury. Adv. Funct. Mater. 2009, 19, 842-852. [CrossRef] 
29. Jalal, R.; Goharshadi, E.K.; Abareshi, M.; Moosavi, M.; Yousefi, A.; Nancarrow, P. ZnO nanofluids: Green synthesis, characterization, and antibacterial activity. Mater. Chem. Phys. 2010, 121, 198-201. [CrossRef]

30. Jones, N.; Ray, B.; Ranjit, K.T.; Manna, A.C. Antibacterial activity of ZnO nanoparticle suspensions on a broad spectrum of microorganisms. FEMS Microbiol Lett. 2008, 279, 71-76. [CrossRef]

31. Zhang, L.; Jiang, Y.; Ding, Y.; Povey, M.; York, D. Investigation into the antibacterial behaviour of suspensions of $\mathrm{ZnO}$ nanoparticles (ZnO nanofluids). J. Nanopart. Res. 2007, 9, 479-489. [CrossRef]

32. Stoimenov, P.K.; Klinger, R.L.; Marchin, G.L.; Klabunde, K.J. Metal oxide nanoparticles as bactericidal agents. Langmuir 2002, 18, 6679-6686. [CrossRef]

33. Heinlaan, M.; Ivask, A.; Blinova, I.; Dubourguier, H.C.; Kahru, A. Toxicity of nanosized and bulk ZnO, $\mathrm{CuO}$ and $\mathrm{TiO}_{2}$ to bacteria Vibrio fischeri and crustaceans Daphnia magna and Thamnocephalus platyurus. Chemosphere 2008, 71, 1308-1316. [CrossRef]

34. Huang, Z.; Zheng, X.; Yan, D.; Yin, G.; Liao, X.; Kang, Y.; Yao, Y.; Huang, D.; Hao, B. Toxicological effect of $\mathrm{ZnO}$ nanoparticles based on bacteria. Langmuir 2008, 24, 4140-4144. [CrossRef] [PubMed]

35. Li, M.; Zhu, L.; Lin, D.V. Toxicity of ZnO nanoparticles to escherichia Coli: Mechanism and the influence of medium components. Environ. Sci. Technol. 2011, 45, 1977-1983. [CrossRef] [PubMed]

36. Mishra, P.K.; Mishra, H.; Ekielski, A.; Talegaonkar, S.; Vaidya, B. Zinc oxide nanoparticles: A promising nanomaterial for biomedical applications. Drug Discov. Today 2017, 22, 1825-1834. [CrossRef]

37. Sawai, J.; Yoshikawa, T. Quantitative evaluation of antifungal activity of metallic oxide powders $(\mathrm{MgO}, \mathrm{CaO}$ and $\mathrm{ZnO}$ ) by an indirect conductimetric assay. J. Appl. Microbiol. 2004, 96, 803-809. [CrossRef] [PubMed]

38. He, L.; Liu, Y.; Mustapha, A.; Lin, M. Antifungal activity of zinc oxide nanoparticles against Botrytis cinerea and Penicillium expansum. Microbiol. Res. 2011, 166, 207-215. [CrossRef] [PubMed]

39. Wang, J.; Lee, J.S.; Kim, D.; Zhu, L. Exploration of Zinc Oxide Nanoparticles as a Multitarget and Multifunctional Anticancer Nanomedicine. ACS Appl. Mater. Interfaces 2017, 9, 39971-39984. [CrossRef]

40. Ostrovsky, S.; Kazimirsky, G.; Gedanken, A.; Brodie, C. Selective cytotoxic effect of ZnO nanoparticles on glioma cells. Nano Res. 2009, 2, 882-890. [CrossRef]

41. De Berardis, B.; Civitelli, G.; Condello, M.; Lista, P.; Pozzi, R.; Arancia, G.; Meschini, S. Exposure to ZnO nanoparticles induces oxidative stress and cytotoxicity in human colon carcinoma cells. Toxicol. Appl. Pharmacol. 2010, 246, 116-127. [CrossRef]

42. Setyawati, M.I.; Tay, C.Y.; Leong, D.T. Effect of zinc oxide nanomaterials-induced oxidative stress on the p53 pathway. Biomaterials 2013, 34, 10133-10142. [CrossRef]

43. Hanley, C.; Layne, J.; Punnoose, A.; Reddy, K.M.; Coombs, I.; Coombs, A.; Feris, K.; Wingett, D. Preferential killing of cancer cells and activated human T cells using ZnO nanoparticles. Nanotechnology 2008, 19, 1-20. [CrossRef]

44. Tripathy, N.; Ahmad, R.; Ko, H.A.; Khang, G.; Hahn, Y.B. Enhanced anticancer potency using an acid-responsive ZnO-incorporated liposomal drug-delivery system. Nanoscale 2015, 7, 4088-4096. [CrossRef]

45. Rasmussen, J.W.; Martinez, E.; Louka, P.; Wingett, D.G. Zinc oxide nanoparticles for selective destruction of tumor cells and potential for drug delivery applications. Expert. Opin. Drug Deliv. 2010, 7, 1063-1077. [CrossRef] [PubMed]

46. Sharma, H.; Kumar, K.; Choudhary, C.; Mishra, P.K.; Vaidya, B. Development and characterization of metal oxide nanoparticles for the delivery of anticancer drug. Artif. Cells Nanomed. Biotechnol. 2016, 44, 672-679. [CrossRef] [PubMed]

47. Ghaffari, S.B.; Sarrafzadeh, M.H.; Fakhroueian, Z.; Shahriari, S.; Khorramizadeh, M.R. Functionalization of $\mathrm{ZnO}$ nanoparticles by 3-mercaptopropionic acid for aqueous curcumin delivery: Synthesis, characterization, and anticancer assessment. Mater. Sci. Eng. C 2017, 79, 465-472. [CrossRef] [PubMed]

48. Agarwal, H.; Nakara, A.; Shanmugam, V.K. Anti-inflammatory mechanism of various metal and metal oxide nanoparticles synthesized using plant extracts: A review. Biomed. Pharmacother. 2019, 109, 2561-2572. [CrossRef] [PubMed]

49. Nagajyothi, P.C.; Cha, S.J.; Yang, I.J.; Sreekanth, T.V.M.; Kim, K.J.; Shin, H.M. Antioxidant and anti-inflammatory activities of zinc oxide nanoparticles synthesized using Polygala tenuifolia root extract. J. Photochem. Photobiol. B Biol. 2015, 146, 10-17. [CrossRef] [PubMed]

50. Elsayed, M.A.; Norredin, A. The Potential Contribution of Nanoparticles in the Treatment of Inflammatory Diseases. In Inflammation-From Molecular Basis to Clinical Outcomes Cause; IntechOpen: London, UK, 2019; pp. 1-15. 
51. Ilves, M.; Palomäki, J.; Vippola, M.; Lehto, M.; Savolainen, K.; Savinko, T.; Alenius, H. Topically applied ZnO nanoparticles suppress allergen induced skin inflammation but induce vigorous IgE production in the atopic dermatitis mouse model. Part. Fibre Toxicol. 2014, 11, 1-12. [CrossRef]

52. Wiegand, C.; Hipler, U.C.; Boldt, S.; Strehle, J.; Wollina, U. Skin-protective effects of a zinc oxide-functionalized textile and its relevance for atopic dermatitis. Clin. Cosmet. Investig. Dermatol. 2013, 6, 115-121. [CrossRef]

53. El-Gharbawy, R.M.; Emara, A.M.; Abu-Risha, S.E.S. Zinc oxide nanoparticles and a standard antidiabetic drug restore the function and structure of beta cells in Type-2 diabetes. Biomed. Pharmacother. 2016, 84, 810-820. [CrossRef]

54. Wahba, N.S.; Shaban, S.F.; Kattaia, A.A.A.; Kandeel, S.A. Efficacy of zinc oxide nanoparticles in attenuating pancreatic damage in a rat model of streptozotocin-induced diabetes. Ultrastruct. Pathol. 2016, 40, 358-373. [CrossRef]

55. Alkaladi, A.; Abdelazim, A.M.; Afifi, M. Antidiabetic activity of zinc oxide and silver nanoparticles on streptozotocin-induced diabetic rats. Int. J. Mol. Sci. 2014, 15, 2015-2023. [CrossRef] [PubMed]

56. Afifi, M.; Almaghrabi, O.A.; Kadasa, N.M. Ameliorative Effect of Zinc Oxide Nanoparticles on Antioxidants and Sperm Characteristics in Streptozotocin-Induced Diabetic Rat Testes. BioMed Res. Int. 2015, 2015, 1-6. [CrossRef] [PubMed]

57. Mohamed, D.A.; Abdelrahman, S.A. The possible protective role of zinc oxide nanoparticles (ZnO NPs) on testicular and epididymal structure and sperm parameters in nicotine-treated adult rats (a histological and biochemical study). Cell Tissue Res. 2019, 375, 543-558. [CrossRef] [PubMed]

58. Torabi, F.; Shafaroudi, M.M.; Rezaei, N. Combined protective effect of zinc oxide nanoparticles and melatonin on cyclophosphamide-induced toxicity in testicular histology and sperm parameters in adult Wistar rats. Int. J. Reprod. Biomed. 2017, 15, 403-412. [CrossRef]

59. El-Maddawy, Z.K.; Abd El Naby, W.S.H. Protective effects of zinc oxide nanoparticles against doxorubicin induced testicular toxicity and DNA damage in male rats. Toxicol. Res. 2019, 8, 654-662. [CrossRef]

60. Isaac, A.V.; Kumari, S.; Nair, R.; Urs, D.R.; Salian, S.R.; Kalthur, G.; Adiga, S.K.; Manikkath, J.; Mutalik, S.; Sachdev, D.; et al. Supplementing zinc oxide nanoparticles to cryopreservation medium minimizes the freeze-thaw-induced damage to spermatozoa. Biochem. Biophys. Res. Commun. 2017, 494, 656-662. [CrossRef]

61. Walker, N.J.; Bucher, J.R. A 21st century paradigm for evaluating the health hazards of nanoscale materials? Toxicol. Sci. 2009, 110, 251-254. [CrossRef]

62. Lan, Z.; Yang, W.X. Nanoparticles and spermatogenesis: How do nanoparticles affect spermatogenesis and penetrate the blood-testis barrier. Nanomedicine 2012, 7, 579-596. [CrossRef]

63. Chen, A.; Feng, X.; Sun, T.; Zhang, Y.; An, S.; Shao, L. Evaluation of the effect of time on the distribution of zinc oxide nanoparticles in tissues of rats and mice: A systematic review. IET Nanobiotechnol. 2016, 10, 97-106. [CrossRef]

64. Abbasalipourkabir, R.; Moradi,H.; Zarei, S.; Asadi, S.; Salehzadeh, A.; Ghafourikhosroshahi, A.; Mortazavi, M.; Ziamajidi, N. Toxicity of zinc oxide nanoparticles on adult male Wistar rats. Food Chem. Toxicol. 2015, 84, 154-160. [CrossRef]

65. Hao, Y.; Liu, J.; Feng, Y.; Yu, S.; Zhang, W.; Li, L.; Min, L.; Zhang, H.; Shen, W.; Zhao, Y. Molecular evidence of offspring liver dysfunction after maternal exposure to zinc oxide nanoparticles. Toxicol. Appl. Pharmacol. 2017, 329, 318-325. [CrossRef] [PubMed]

66. Kuang, H.; Yang, P.; Yang, L.; Aguilar, Z.P.; Xu, H. Size dependent effect of ZnO nanoparticles on endoplasmic reticulum stress signaling pathway in murine liver. J. Hazard. Mater. 2016, 317, 119-126. [CrossRef] [PubMed]

67. Lin, F.Y.; Chiu, J.I.; Cheng, Y.F.; Lee, H.Y.; Wang, J.Y.; Hsu, H.Y.; Chiu, W.H. The role of hypoxia-inducible factor- $1 \alpha$ in zinc oxide nanoparticle-induced nephrotoxicity in vitro and in vivo. Part. Fibre Toxicol. 2015, 13, 1-14. [CrossRef] [PubMed]

68. Cheng, C.Y.; Wong, E.W.P.; Yan, H.H.N.; Mruk, D.D. Regulation of Spermatogenesis in the Microenvironment of the Seminiferous Epithelium: New Insights and Advances. Mol. Cell. Endocrinol. 2010, 315, 49-56. [CrossRef] [PubMed]

69. De Kretser, D.M.; Loveland, K.L.; Meinhardt, A.; Simorangkir, D.; Wreford, N. Spermatogenesis. Hum. Reprod. 1998, 13, 1-8. [CrossRef]

70. Liu, Q.; Xu, C.; Ji, G.; Liu, H.; Mo, Y.; Tollerud, D.J.; Gu, A.; Zhang, Q. Sublethal effects of zinc oxide nanoparticles on male reproductive cells. Toxicol. In Vitro 2016, 35, 131-138. [CrossRef] 
71. Han, Z.; Yan, Q.; Ge, W.; Liu, Z.-G.; Gurunathan, S.; De Felici, M.; Shen, W.; Zhang, X.-F. Cytotoxic effects of ZnO nanoparticles on mouse testicular cells. Int. J. Nanomed. 2016, 11, 5187-5203. [CrossRef]

72. Li, M.W.M.; Wong, V.; Szeto, L.; Uffelman, K.; Fantus, I.G.; Lewis, G.F. Tumor necrosis factor $\alpha$ reversibly disrupts the blood-testis barrier and impairs Sertoli-germ cell adhesion in the seminiferous epithelium of adult rat testes. J. Endocrinol. 2006, 190, 313-329. [CrossRef]

73. Hellani, A.; Ji, J.; Mauduit, C.; Deschildre, C.; Tabone, E.; Benahmed, M. Developmental and hormonal regulation of the expression of oligodendrocyte-specific protein/claudin $11 \mathrm{in}$ mouse testis. Endocrinology 2000, 141, 3012-3019. [CrossRef]

74. Barkhordari, A.; Hekmatimoghaddam, S.; Jebali, A.; Khalili, M.A.; Talebi, A.; Noorani, M. Effect of zinc oxide nanoparticles on viability of human spermatozoa. Iran. J. Reprod. Med. 2013, 11, 767-771.

75. Shen, J.; Yang, D.; Zhou, X.; Wang, Y.; Tang, S.; Yin, H.; Wang, J.; Chen, R.; Chen, J. Role of Autophagy in Zinc Oxide Nanoparticles-Induced Apoptosis of Mouse LEYDIG Cells. Int. J. Mol. Sci. 2019, 20, 4042. [CrossRef] [PubMed]

76. Talebi, A.R.; Khorsandi, L.; Moridian, M. The effect of zinc oxide nanoparticles on mouse spermatogenesis. J. Assist. Reprod. Genet. 2013, 30, 1203-1209. [CrossRef] [PubMed]

77. Mozaffari, Z.; Parivar, K.; Roodbari, N.H.; Irani, S. Histopathological evaluation of the toxic effects of zinc oxide $(\mathrm{ZnO})$ nanoparticles on testicular tissue of NMRI adult mice. Adv. Stud. Biol. 2015, 7, 275-291. [CrossRef]

78. Hussein, M.M.A.; Ali, H.A.; Saadeldin, I.M.; Ahmed, M.M. Querectin Alleviates Zinc Oxide Nanoreprotoxicity in Male Albino Rats. J. Biochem. Mol. Toxicol. 2016, 30, 489-496. [CrossRef] [PubMed]

79. O’Donnell, B.; Huo, L.; Polli, R.; Qiu, L.; Collier, N.; Zhang, B.; Pan, X. ZnO nanoparticles enhanced germ cell apoptosis in Caenorhabditis elegans. In comparison with $\mathrm{ZnCl}_{2}$. Toxicol. Sci. 2017, 156, 336-343. [CrossRef]

80. Salman, R.A. The Influence of ZnO NPs on Reproductive System Tissues of Albino Male Mice. Histopathological Study. Int. J. Sci. Res. 2017, 6, 2021-2025. [CrossRef]

81. Srivastav, A.K.; Kumar, A.; Prakash, J.; Singh, D.; Jagdale, P.; Shankar, J.; Kumar, M. Genotoxicity evaluation of zinc oxide nanoparticles in Swiss mice after oral administration using chromosomal aberration, micronuclei, semen analysis, and RAPD profile. Toxicol. Ind. Health 2017, 33, 821-834. [CrossRef]

82. Aporvari, H.A.; Mamoei, M.; Vakili, S.T.; Zareei, M.; Davachi, N.D. The effect of oral administration of zinc oxide nanoparticles on quantitative and qualitative properties of arabic ram sperm and some antioxidant parameters of seminal plasma in the non-breeding season. Arch. Razi Inst. 2018, 73, 121-129. [CrossRef]

83. Khoobbakht, Z.; Mohammadi, M.; Mehr, M.R.A.; Mohammadghasemi, F.; Sohani, M.M. Comparative effects of zinc oxide, zinc oxide nanoparticle and zinc-methionine on hatchability and reproductive variables in male Japanese quail. Anim. Reprod. Sci. 2018, 192, 84-90. [CrossRef]

84. Radhi, M.J.; Al-bairuty, G. Effect of Zinc oxide nanoparticles (ZnO-NPs) on weights of some reproductive organs and sperm abnormalities in the tail of epididymis of albino mice. J. Pharm. Sci. Res. 2019, 11, 243-246.

85. Mesallam, D.I.; Deraz, R.H.; Aal, S.M.A.; Ahmed, S.M. Toxicity of Subacute Oral Zinc Oxide Nanoparticles on Testes and Prostate of Adult Albino Rats and Role of Recovery. J. Histol. Histopathol. 2019, 6, 1-11. [CrossRef]

86. Tang, Y.; Chen, B.; Hong, W.; Chen, L.; Yao, L.; Zhao, Y.; Aguilar, Z.P.; Xu, H. ZnO Nanoparticles Induced Male Reproductive Toxicity Based on the Effects on the Endoplasmic Reticulum Stress Signaling Pathway. Int. J. Nanomed. 2019, 14, 9563-9576. [CrossRef] [PubMed]

87. Ewing, L.L.; Zirkin, B. Leydig cell structure and steroidogenic function. Recent Prog. Horm. Res. 1983, 39, 599-635. [CrossRef] [PubMed]

88. Payne, A.H.; Hardy, M.P. The Leydig Cell in Health and Disease; Springer: Berlin/Heidelberg, Germany, 2007.

89. Wang, H.; Wang, Q.; Zhao, X.F.; Liu, P.; Meng, X.H.; Yu, T.; Ji, Y.L.; Zhang, H.; Zhang, C.; Zhang, Y.; et al. Cypermethrin exposure during puberty disrupts testosterone synthesis via downregulating StAR in mouse testes. Arch. Toxicol. 2010, 84, 53-61. [CrossRef] [PubMed]

(C) 2020 by the authors. Licensee MDPI, Basel, Switzerland. This article is an open access article distributed under the terms and conditions of the Creative Commons Attribution (CC BY) license (http://creativecommons.org/licenses/by/4.0/). 